2008s-14

\title{
Risk Retention Groups in Medical Malpractice Insurance: A Test of the Federal Chartering Option
}

\author{
Patricia Born, M. Martin Boyer
}

\begin{tabular}{c}
\hline Série Scientifique \\
Scientific Series
\end{tabular}

Montréal

Mai 2008

(C) 2008 Patricia Born, M. Martin Boyer. Tous droits réservés. All rights reserved. Reproduction partielle permise avec citation du document source, incluant la notice (C).

Short sections may be quoted without explicit permission, if full credit, including (C) notice, is given to the source.
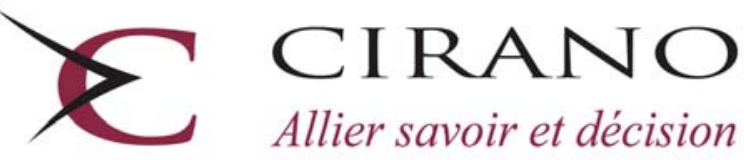

Allier savoir et décision

Centre interuniversitaire de recherche en analyse des organisations 


\section{CIRANO}

Le CIRANO est un organisme sans but lucratif constitué en vertu de la Loi des compagnies du Québec. Le financement de son infrastructure et de ses activités de recherche provient des cotisations de ses organisations-membres, d'une subvention d’infrastructure du Ministère du Développement économique et régional et de la Recherche, de même que des subventions et mandats obtenus par ses équipes de recherche.

CIRANO is a private non-profit organization incorporated under the Québec Companies Act. Its infrastructure and research activities are funded through fees paid by member organizations, an infrastructure grant from the Ministère du Développement économique et régional et de la Recherche, and grants and research mandates obtained by its research teams.

\section{Les partenaires du CIRANO}

\section{Partenaire majeur}

Ministère du Développement économique, de l’Innovation et de l’Exportation

\section{Partenaires corporatifs}

Alcan inc.

Banque de développement du Canada

Banque du Canada

Banque Laurentienne du Canada

Banque Nationale du Canada

Banque Royale du Canada

Banque Scotia

Bell Canada

BMO Groupe financier

Bourse de Montréal

Caisse de dépôt et placement du Québec

DMR Conseil

Fédération des caisses Desjardins du Québec

Gaz de France

Gaz Métro

Hydro-Québec

Industrie Canada

Investissements PSP

Ministère des Finances du Québec

Raymond Chabot Grant Thornton

State Street Global Advisors

Transat A.T.

Ville de Montréal

\section{Partenaires universitaires}

École Polytechnique de Montréal

HEC Montréal

McGill University

Université Concordia

Université de Montréal

Université de Sherbrooke

Université du Québec

Université du Québec à Montréal

Université Laval

Le CIRANO collabore avec de nombreux centres et chaires de recherche universitaires dont on peut consulter la liste sur son site web.

Les cahiers de la série scientifique (CS) visent à rendre accessibles des résultats de recherche effectuée au CIRANO afin de susciter échanges et commentaires. Ces cahiers sont écrits dans le style des publications scientifiques. Les idées et les opinions émises sont sous l'unique responsabilité des auteurs et ne représentent pas nécessairement les positions du CIRANO ou de ses partenaires.

This paper presents research carried out at CIRANO and aims at encouraging discussion and comment. The observations and viewpoints expressed are the sole responsibility of the authors. They do not necessarily represent positions of CIRANO or its partners. 


\title{
Risk Retention Groups in Medical Malpractice Insurance: A Test of the Federal Chartering Option
}

\author{
Patricia Born ${ }^{*}$, M. Martin Boyer ${ }^{\dagger}$
}

\begin{abstract}
Résumé / Abstract
La crise des assurances de la responsabilité civile qu'ont connue les États-Unis au milieu des années 80 a mené le gouvernement fédéral à légiférer pour augmenter le nombre d'assureurs au pays via le Liability Risk Retention Act de 1986. Cette loi a permis la création d'un nouveau type d'assureurs, les risk retention groups (RRG), qui sont régis par une charte quasi-fédérale contrairement aux assureurs traditionnels qui doivent obtenir un permis d'exploitation dans chaque état américain. Nous utilisons ces RRG dans notre étude pour évaluer la pertinence d'autoriser les assureurs américains d’être incorporés et réglementés par le gouvernement fédéral plutôt qu'au niveau des états individuellement. En utilisant des données de la National Association of Insurance Commissioners, nous examinons si la présence des RRG a augmenté la compétition et la disponibilité de produits d'assurance de la responsabilité civile des professionnels de la médecine. Nous évaluons ainsi les bénéfices pour les assurés et la société de permettre aux assureurs d'être réglementés et incorporés au niveau fédéral.
\end{abstract}

Mots clés : assurance de la responsabilité civile, charte fédérale optionnelle, disponibilité des assurances, contrats CMR.

The liability crisis of the eighties led to the enactment of the federal Liability Risk Retention Act of 1986, which encouraged the formation of risk retention groups, a new organizational form that is incorporated under a federal charter. We use risk retention groups as a proxy for insurers opting for a federal charter and assess empirically the economic viability of an optional federal charter. Using annual data from the National Association of Insurance Commissioners, we assess whether risk retention groups increase insurance availability and competition in the medical malpractice insurance industry. We consider the insurers' use of two different types of insurance contracts, namely occurrence contracts and claims-made and reported contracts, and evaluate the benefits to policyholders and society of insurers having access to an optional federal charter, while remaining under state regulatory and solvency controls.

Keywords: medical malpractice insurance, optional federal charter, insurance availability, claims-made contracts.

\footnotetext{
* Department of Finance, Real Estate and Insurance, California State University, Northridge, 18111 Nordhoff St., Northridge, CA 91330-8379, patricia.born@csun.edu.

${ }^{\dagger}$ M. Martin Boyer, PhD, Département de Finance, HEC Montréal, Université de Montréal, 3000, chemin de la Côte-Ste-Catherine, Montréal, Québec, H3T2A7, martin.boyer@hec.ca.
} 


\section{Introduction}

The goal of this paper is to assess, albeit indirectly, the economic consequences on the property and casualty insurance industry of introducing in the United States Senate the "National Insurance Act of 2006" (and the modifications to it in the Senate and House bills that were reintroduced in 2007) that aims to modernize the regulation of the insurance industry in these times of consolidation in the greater financial services arena. This Act would create an Office of National Insurance whose commissioner would be authorized to "issue federal charters and licenses to insurers, and to regulate exclusively their operations and solvency. ${ }^{1}$ Presumably, the end goal of such legislation is to increase the availability and adequacy of insurance products in the United States and to reduce the solvency risk of companies that provide these policies. The problem is that there has been no clear test of whether this approach would indeed achieve its goal, at least in the property and casualty lines of business. ${ }^{2}$

The current paper fills that void by focusing on the availability, profitability and operations of insurers in a very precise line of property and casualty insurance: medical malpractice insurance. The medical malpractice insurance industry has been systematically one of the most scrutinized insurance lines, due to periodic performance "crises" - evidenced by increasing premiums and reduced availability of liability coverage. Amid ongoing concerns for the rising cost of health care and an increase in the number of uninsured individuals for health care services, it is not surprising that medical malpractice insurers' operations are called to question, at least to the extent that patients' access to care is disrupted because of non-renewal of medical malpractice insurance coverage, which causes providers to reduce services. ${ }^{3}$ The performance crises have prompted a variety of legislative responses including, for example, legal reforms and the implementation of

\footnotetext{
${ }^{1}$ See Hal S. Scott (2007), Optional Federal Chartering of Insurance: Design of a Regulatory Structure, Harvard Law School Public Law Research Paper no 07-05.

${ }^{2}$ For the life and annuity lines of business, see Martin F. Grace and Robert W. Klein (2007), The Effects of an Optional Federal Charter on Competition in the Life Insurance Industry, Center for Risk Management and Insurance Research Working Paper, Georgia State University.
}

${ }^{3}$ A GAO (2003) report of four states cites mixed evidence that increasing malpractice premiums are related to physician supply. 
state victim compensation funds. The reason we choose this particular line of business is that is it very popular among a new and growing organizational form of insurers, known as risk retention groups (RRGs). The formation of RRGs was prompted and encouraged by the federal Liability Risk Retention Act of 1981 (amended in 1986). This Act encouraged the formation of risk retention groups (RRG), a new organizational form where insurers who are incorporated under such a system enjoy rights and privileges that are not accessible to other state-licensed insurance companies. In a sense, risk retention groups enjoy the same rights as federally chartered insurers.

Risk retention groups are distinct from other physician-owned insurance companies, such as mutual and reciprocal insurers or closely-held stock insurance companies, not in their heightened sense of loss control, for all physician-owned insurers generate this benefit, but in their incorporation under a quasi-federal charter. This charter comes at the price of accepting limitations in terms of insurance program scope and of access to informal capital markets. For instance, members forming a risk retention group must be engaged in similar activities and have similar risk exposures, thus reducing the ability to diversify across different types of risk.

Although risk retention groups are typically formed to meet the needs of a local group of providers, once it is licensed, it may enter additional states. Risk retention groups are regulated by the states in which they organize, but they are not protected by state guaranty funds. Interestingly, the legislation that would bring to life federally chartered insurance companies would also need the federal government to set up a guarantee fund. Today, close to 150 risk retention groups that specialize in medical malpractice liability insurance operate, compared to about 20 in 1998.

We use RRGs as a proxy for insurers opting for a federal charter and assess empirically the economic viability of an optional federal charter. This approach draws some validity in the fact that the American Insurance Association, the leading trade group for property and liability insurers, floated the idea of extending the legislation ${ }^{4}$ that allowed risk retention groups to operated to more property and casualty lines of business prior to

${ }^{4}$ See Scott Harrington (2006), Federal Chartering of Insurance Companies: Options and Alternatives for Transforming Insurance Regulation, Networks Financial Institute policy brief 2006-PB-02. 
proposing the concept of optional federal chartering of property and liability insurance companies.

Using annual data by company and by state obtained from the National Association of Insurance Commissioners, we will assess whether RRGs increase insurance availability and competition in the medical malpractice insurance industry. This should allow us to evaluate the public policy implication of optional federal charters.

As of now, discussion on an optional federal charter has been mainly focused on the life insurance industry, ${ }^{5}$ perhaps because there are more insurers and intermediaries opposed to optional federal charter in the property and casualty industry. What appears to be the most important reason for introducing such a charter is the feeling that the 50odd life insurance regulatory jurisdictions in the United States slow down innovation in the life insurance industry in the face of mounting competition from alien (i.e., non-U.S. base) insurance companies. The American Council of Life Insurers estimates that "it can take life insurers two years to gain the approval of all 51 insurance regulatory bodies" ${ }^{6}$ to bring a new product to market nationwide under the current system compared to only 60 days for under a federal system.

Although the battle is being fought on the life insurance field because life insurance products face stiffer competition from products developed by federally regulates asset management firms than property and casualty insurance products, it is only a matter of time before the property and casualty insurance industry becomes entangled in the debate. ${ }^{7}$ This is evident from the public position adopted by the American Insurance

\footnotetext{
${ }^{5}$ Martin F. Grace and Robert W. Klein (2007), The Effects of an Optional Federal Charter on Competition in the Life Insurance Industry, Center for Risk Management and Insurance Research Working Paper, Georgia State University.

${ }^{6}$ Kim Dorgan, Executive Vice President of the American Council of Life Insurers, quoted in Insurance and Technology, November 142007.

7 See Scott Harrington (2006), Federal Chartering of Insurance Companies: Options and Alternatives for Transforming Insurance Regulation, Networks Financial Institute policy brief 2006-PB-02; and Hal S. Scott (2007), Optional Federal Chartering of Insurance: Design of a Regulatory Structure, Harvard Law School Public Law Research Paper no 07-05.
} 
Association in favor of optional federal chartering. Their main argument is that the statecum-federal regulatory banking system is more efficient than the "present patchwork state regulatory system." ${ }^{\prime 8}$ The National Association of Mutual Insurance Companies on the other hand argue that this bill "would create a system that the vast majority of companies and agents in the property/casualty world strongly oppose." ${ }^{9}$ The National Association of Insurance Commissioners is also strongly opposed to the idea of optional federal charters.

The remainder of the paper goes as follows. We next describe the structure of RRGs and their specificities in the insurance market landscape as the only insurance ownership form that results from a federal charter. We also present in section 2 the theoretical foundations of the use of claims-made and reported insurance contract because they are so intimately related to risk retention groups. In Section 3 we present our empirical analysis by examining whether risk retention groups, that act as a proxy for our analysis of having an optional federal charter, increase availability in the medical malpractice insurance market. We shall see that risk retention groups do indeed increase availability by reducing the market power of traditional medical malpractice insurance providers. The section includes additional analysis of the role that risk retention groups play in the medical malpractice market, notably their scale and scope of operations. Finally we conclude in Section 5 and offer avenues for future research.

\section{Industry background}

\subsection{Background on Optional Federal Charter (OFC)}

Talks about an optional federal charter have been going on for a long time, probably even since the enactment of the McCarran-Ferguson Act of 1945 in which the Federal government delegated insurance regulatory supervision to the states. Although the insurance industry was much in favor of such a delegation of power to the states then,

\footnotetext{
${ }^{8}$ Marc Racicot, president of the American Insurance Association, quoted in the Insurance Journal, April 52006.

${ }^{9}$ Justin Roth, Senior federal affairs director of the National Association of Mutual Insurance Companies, quoted in the Insurance Journal, May 252007.
} 
the size and scope of both the life insurance and the property and casualty insurance industries have increase by so much since that the economic environment and the level of competitiveness of the industry may, today, warrant a new look at a possible national oversight. A possible explanation for these insurers to have been satisfied with state regulation was that the first insurance companies were very small and confined to a specific state or region within the state. ${ }^{10}$

In other countries (such as Canada where financial institutions can obtain a federal charter or a provincial charter) and in other markets (such as the banking sector in the United States) the dual system is working relatively well, although some attribute the savings-and-loans debacle of the eighties in the United States to "a regulatory race to the bottom... that left customers without the protection they needed." 11

Scott (2007) argues $^{12}$ that the possibility for insurance companies to obtain a letter of incorporation under a federal charter should lead to more regulatory consolidation and less fragmentation. If this is the case, the threat of letting insurance companies be incorporated at the federal level could induce the states to accelerate their convergence toward some type of common regulation. But then one need to wonder, as in Grace and Klein (2007), ${ }^{13}$ what would be the advantage of having 51 state regulatory bodies with the same regulation instead of a unique federal regulator.

The implementation of an optional federal charter requires establishment of a parallel system of regulation and supervision for insurers, agents and brokers. This dual system

${ }^{10}$ See Martin F. Grace and Robert W. Klein (2007), The Effects of an Optional Federal Charter on Competition in the Life Insurance Industry, Center for Risk Management and Insurance Research Working Paper, Georgia State University.

${ }^{11}$ Len Brevik, Executive Vice President and Chief Executive Officer of the National Association of Professional Insurance Agents, quoted in PIA Connection, August 12006.

${ }^{12}$ Hal S. Scott (2007). Optional Federal Chartering of Insurance: Design of a Regulatory Structure, Harvard Law School Public Law Research Paper no 07-05.

${ }^{13}$ Martin F. Grace and Robert W. Klein (2007), The Effects of an Optional Federal Charter on Competition in the Life Insurance Industry, Center for Risk Management and Insurance Research Working Paper, Georgia State University. 
might be confusing, in particular for consumers who purchase some policies that are state-regulated and others that are federally-regulated. A dual chartering system for the US banking industry has been in place since 1863. Viewed largely a successful system, the charter offers a choice for managers of banks and credit unions, which some argue creates healthy tension among regulators and increased innovation among financial service products. ${ }^{14}$

An important component of the debate over offering the optional federal charter to property and casualty firms may be the specific lines and markets for which the charter would be allowed. The complexities in some lines of insurance, such as workers compensation and medical malpractice, may complicate the move, while large commercial lines may not be a problem given their current protections. ${ }^{15}$

As one can see, the insurance industry is divided on the optional federal charter issue. On the one hand, the National Association of Mutual Insurance Companies (NAMIC) and the Independent Insurance Agents \& Brokers of America (IIABA), argue that local regulation works better for consumers. Moreover, by adding an extra layer of regulation, costs would increase, which would ultimately hurt consumers because they would face greater premiums, not to mention potential coverage gaps. Proponents of the federal charter, on the other hand, say the current system is full of conflicting regulations including market conduct rules, pricing provisions, guarantee funds and other licensing provisions. They argue that a federal system would improve ability to monitor solvency. The American Council of Life Insurers argues that their members could "save more than 5.7 billion dollars annually if they functioned under a single regulator." 16 Other industry members, such as the National Association of Insurance and Financial Advisors, have not taken position yet in favor or against the existence of an optional federal charter.

\footnotetext{
${ }^{14}$ See White, Eugene Nelson (1982). The Political Economy of Banking Regulation, 1864-1933.

${ }^{15}$ Paul Kanjorski, D-Pa., chair of the House Financial Services Subcommittee on Capital Markets, Insurance and Government Sponsored Enterprises, speaking in a congressional briefing that was part of the 2007 Insurance Legislative Summit

${ }^{16}$ Kim Dorgan, Executive Vice President of the American Council of Life Insurers, quoted in Insurance and Technology, November 142007.
} 
One main question that policymakers must ask with respect to optional federal charters is whether they will increase the level of competitiveness in the industry and increase the welfare of consumers. The debate with respect to this question centers on the question of insurer solvency, service to policyholders and overall regulation of the market.

\subsection{Background on Risk Retention Groups}

The federal Liability Risk Retention Act of 1981 (which was amended in 1986) encouraged the formation of risk retention groups (RRG) for liability coverage, except workers' compensation insurance. The Act specifies that the members forming an RRG must be engaged in similar activities, so that they are exposed to similar risks. There is thus little diversification in the insurer's exposure portfolio since all policyholders are faced with similar risks. One final important risk-bearing limitation of RRG is that their policyholders-owners are not allowed to gain access to state guaranty funds in case of insolvency.

\section{Figure 1. Number and market share of risk retention groups, 1992-2006.}

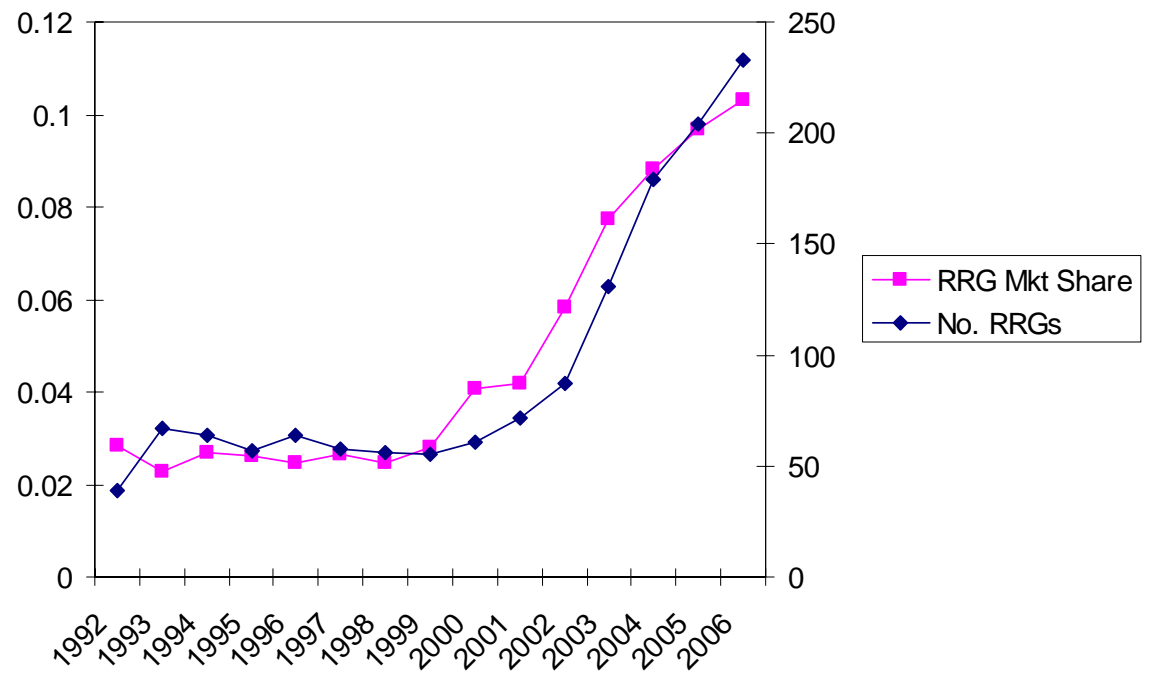

Source: NAIC data tapes and authors’ calculations

As we can see in Figure 1, risk retention groups became mostly popular at the beginning of the $21^{\text {st }}$ century, even though the Act that allowed for their existence was passed almost fifteen years earlier. The number of RRGs quadrupled since the year 2000, whereas the market share of RRGs went from close to $3 \%$ of the market to almost $10 \%$ during the same time period. Risk retention groups may be incorporated as stock companies, not-for-profit organizations, insurance exchanges, etc... The only thing that 
differentiates a risk retention group from any other organizational form is its incorporation under a federal charter.

Suppose one were to rank the ownership structure from the form that has more risk bearing ability to the form that has the least risk bearing ability, one would clearly list the stock companies as having the highest ability because it can easily raise extra capital to compensate for an unexpected catastrophic loss. What ownership structure would rank the lowest in terms of risk bearing capacity? We would argue that risk retention groups have the lowest ability to absorb a catastrophic loss, and so for two reasons: the absence of an internal capital market and the low diversification of their risk portfolio.

The reason we say that risk retention groups have little ability to assume a catastrophic loss is that a federal law ${ }^{17}$ prohibits RRG from insuring personal lines of insurance, such as homeowner and automobile insurance. This reduces an RRG's ability to profit from any economies of scope in providing a full range of insurance services. Furthermore, there is no possibility for policyholders to use their option to access the insurer's other lines surplus (see Phillips et al., 1998) since there are no other line. Moreover, because policyholders insured by risk retention groups must be operating in the same line of business, at least in terms of the liability exposure, there is little diversification in the exposure portfolio since all policyholders are exposed to the same risk. It will therefore be impossible the manager of an RRG to raise capital internally in bad times because there is no diversification of insurance lines or of risk exposure.

One final important risk bearing ability limitation of RRG is that their policyholdersowners are not allowed to gain access to state guaranty funds in case of insolvency. This reduces furthermore the ability of an RRG to gain access to outside funding since it cannot consider the state guaranty fund as the short end counterparty of an implicit put option transaction.

\subsection{Background on medical malpractice insurance}

Attempts to explain problems in the medical malpractice insurance industry typically examine the influence of exogenous factors on the performance of the member insurers. These exogenous factors include increased litigation by patients, increased jury verdicts

\footnotetext{
${ }^{17}$ Federal Risk Retention Group Statute, 15 U.S.C. § 3902.
} 
and out-of-court settlements, falling investment income, rising reinsurance rates, and changes in the legal environment. Interestingly, little attention has been devoted to developments within the industry and their potential influence on insurer performance such as claims-made policies and, more related to our research, to physician-owned mutual insurers, reciprocals, and risk retention groups.

One could easily claim that the liability crisis in the medical malpractice insurance industry of the seventies led to the introduction of claims-made and reported policies, tort reforms, and the creation of state joint underwriting associations, whereas the availability crisis of the eighties led to the federal Liability Risk Retention Act of 1981 (amended in 1986), and the subsequent formation of risk retention groups.

As a result, the recent dramatic growth among risk retention groups has been in the medical malpractice insurance market. While state legislated tort reforms, such as caps on noneconomic damages, have successfully addressed some components of the periodic medical malpractice crises (i.e., in the 1970s, 1980s and late 1990s), availability appears to be an ongoing issue for certain groups of medical providers. The hard market in the early 2000s may have been the greatest impetus for the formation of RRGs by medical providers, although the softening of the market in 2005 has not caused a slowdown. Medical-related RRGs have been formed in some cases by groups of specialists such as orthodontists and ophthalmologists, and in other cases by similar facilities, such as skilled nursing facilities. They now account for almost half of all RRGs in operation.

In the medical malpractice arena, the Act basically allows medical care providers, including physician groups and hospitals, to obtain more control over their insurance programs. The price for this heightened sense of control over losses and premium is accepting limitations in terms of insurance program scope and in terms of a limited access to the formal and informal capital markets.

\subsection{Claims-made and reported policies}

Of course, one cannot talk about risk retention groups without talking about the differences between occurrence (OCC) coverage and claims-made and reported (CMR) coverage. The reason is that the market share of RRGs in the OCC market is $13 \%$ compared to $30 \%$ in the CMR market. Under occurrence coverage, a loss incurred in a 
given year is covered by the contract for that year, regardless of when the claim is reported. In contrast, a claims-made policy pays only the claims reported in the policy year. Compared to RRGs, mutual insurance companies, are more likely to sell occurrence-only than CMR-only insurance contracts, but less so than stock companies.

Claims-made policies are argued to reduce the uncertainty associated with writing longtail liability lines (including the uncertain legal environment as in Doherty, 1991). Another possible theory that explains the emergence of the CMR contract from the point of view of the industry is that it helps to retain the policyholder with the industry, if not with the insurer. Because of the CMR contract's retro date that usually goes back only as fare as the initial uninterrupted CMR contract was purchased, it becomes very costly for a risk averse policyholder to jump back and forth from being insured, then uninsured, then insured again. Similarly, it is extremely costly to go from a CMR contract to an occurrence contract because one needs to purchase a retroactive occurrence contract that covers all previous possible incidents, on top of covering the current ones for all future claims filed.

\section{Theoretical framework}

The core of our theoretical framework is that comparing risk retention groups to other types of insurers in the medical malpractice insurance industry gives us a good understanding of the role of optional federal charters in property and liability lines of insurance. For this theory to be valid, we obviously need to know why a P\&L insurer would opt for a federal charter instead of a state charter and relate that to the reasons why a medical malpractice insurer would opt for a risk retention group organizational form instead of forming a stock, mutual or reciprocal insurance company. We are then led to ask the following question: What is the advantage of an RRG so that it could coexist with other policyholder-owned insurance companies?

The coexistence of different organizational forms in the insurance industry is a curiosity, generating a substantial amount of research. ${ }^{18}$ With insurers now choosing the RRG route, we note another twist to this puzzling phenomenon. We know, for instance, that

\footnotetext{
${ }^{18}$ See, for example, Mayers, D. and C.W. Smith, Jr. (1988) Ownership Structure Across Lines of Property-Casualty Insurance, Journal of Law and Economics 31: 351-378; and Ligon, James A. and Paul D. Thistle, The Organizational Structure of Insurance Companies: The Role of Heterogeneous Risks and Guaranty Funds, Journal of Risk and Insurance 74(4): 851-862.
} 
RRGs can be incorporated as a stock insurer, a mutual, a reciprocal, an insurance exchange or a not-for-profit organization. We can then wonder what differences there are between an RRG and a classic policyholder-owned stock company. Stated differently, why would policyholders who intend to create their own captive insurer prefer to form a wholly-owned risk retention group instead of a wholly-owned stock insurance company. When one analyzes the decision of a group of policyholders to setup their own insurance company as a stock insurer or a mutual insurer, the arguments in favor or against each organizational form usually revolve around the questions of access to capital, insurance pricing and loss control. With respect to risk retention groups, however, these arguments are moot since stock risk retention groups have the same access to capital, insurance pricing and loss control techniques as classic, state-incorporated stock insurance companies. The only difference in the traditional bag of arguments that a policyholder might see between a stock RRG and a stock insurance company lies in the solvency protection that a policyholder obtains... but having a policy with a classic stock insurance company provides more protection incase of insolvency than a RRG.

It is clear that risk homogeneity should enhance the loss control and claims management abilities of RRGs. But this should also be available to mutual and reciprocal insurers that could voluntarily limit the scope of their operations. Although the constraint faced by an RRG is more binding than for mutual insurers, it is nevertheless difficult to imagine that it is a sufficient reason to explain the existence of RRGs.

A second more probable explanation to the existence of RRGs is the fact that they are regulated though a federal statute rather than the states. This federal statute explains why an RRG cannot access state guaranty funds in the event of insolvency. And although RRGs were typically formed to meet the needs of a local group of providers, once it is licensed, it may enter additional states. As a result many of the RRGs that formed in the early 2000s decided to be domiciled in Vermont due to the state's particular captive laws that allow greater flexibility. While regulators generally agree that RRGs have helped increase the availability of liability coverage, there are some lingering concerns about the wide variation in state regulatory practices (GAO, 2005). For instance, are the RRGs' reserving practices more or less conservative than the other insurers'? On the one hand, one could imagine that because of their lower regulatory and governance oversight RRGs would be more aggressive in its reserving practices (i.e., reserving errors would be more likely). On the other hand, RRGs do not have as 
easy an access to internal and external capital markets in bad times as other insurance company organizational form so that managers should put more time and effort in anticipating and evaluating correctly future losses (i.e., reserving errors would be less likely).

As a result, the only advantage of being an RRG over a state-incorporated stock company that survives close scrutiny must come from the regulatory side rather than the financial and/ or economic side of the business. One of the greatest regulatory advantages of RRGs is their ability to find business in a state in which they are not domiciled without having to seek regulatory approval in that state. As the Liability Risk Retention Act of 1981 (amended in 1986) states, a risk retention group is bound by the regulation and rules of the state in which it is domiciled.

We can clearly see the similarities between an insurance company that is considered a risk retention group and an insurer that would opt for a federal charter. What an RRG loses from the protection of its policyholders in the event of bankruptcy, it gains in terms of operational and governance flexibility. This is made even clearer when we realize that risk retention groups can be organized as a stock company, a mutual or reciprocal insurer or as an insurance exchange. And similar to traditional insurance companies that can change organizational forms (i.e., demutualize), risk retention groups can change their ownership structure from a mutual RRG to a stock RRG, whether owned by members or by a holding company.

The simple test we therefore conduct in this paper is whether the presence of an optional federal charter in the property and liability insurance lines of business improves the availability of coverage, assuming there was excess demand initially. ${ }^{19}$ For our tests,

\footnotetext{
${ }^{19}$ In a companion paper, we assess why risk retention groups expand into certain state, after they have already formed in one state. What drives the expansion? Is it excess demand? We also estimate in that same companion paper a disequilibrium model and see if the presence of risk retention groups reduces excess demand. See Patricia Born and Martin Boyer (2008), ClaimsMade and Reported Policies and Insurer Profitability in Medical Malpractice, CIRANO working paper 2008s-15.
} 
we use RRGs as the best possible approximation of the possible impact of introducing an optional federal charter.

\section{Empirical Analysis}

Our analysis of the impact of risk retention groups on the availability of medical malpractice insurance follows the traditional approach in the insurance market structure, with a focus on concentration and profitability. Our market analysis includes a twist in that we acknowledge that medical malpractices insurers sell two types of contracts (claims-made or occurrence) designed, presumably, to cater to the needs of different types of policyholders. As such, it seems important to examine and study the relationship between the contract type and the ownership structure of the insurance provided (mutual, stock or RRG).

\subsection{Data}

We use 15 years of data for all insurers writing medical malpractice coverage that filed their Annual statements (1992 - 2006) to the National Association of Insurance Commissioners. We analyze the market structure at the firm-state level. Table 1 provides the important descriptive statistics for our sample of firms.

\begin{tabular}{|l|c|c|}
\hline \multicolumn{3}{|c|}{ Table 1. Descriptive statistics (N=750) } \\
\hline \multicolumn{1}{|c|}{ Variable } & Mean & $\begin{array}{c}\text { Standard } \\
\text { deviation }\end{array}$ \\
\hline State Herfindahl index & 0.210 & 0.095 \\
\hline RRG share of medical malpractice insurance in state & 0.046 & 0.060 \\
\hline State loss ratio & 0.647 & 0.353 \\
\hline State unemployment rate & 4.944 & 1.319 \\
\hline Number of medical malpractice insurers in state & 62.387 & 16.666 \\
\hline
\end{tabular}

It is important to note that the NAIC's coding of a risk retention group was not robust in the early years of the sample because an insurer, whether it is a risk retention group or not, could be incorporated as a stock company and was coded as such in the NAIC database. To circumvent this problem, we verified the coding of RRGs by hand using information obtained from Risk Retention Reporter (2007). 


\subsection{Results}

\subsubsection{Market concentration and insurer profitability}

Our first main testable hypothesis is that market concentration of the medical malpractice liability insurance industry should be lower if risk retention groups have a larger market share in the state. The main reason for our hypothesis is that risk retention groups are federally incorporated, which allows this organizational form to compete in a state without having to find regulatory approval by the local insurance commissioner. As a result, risk retention group market shares are distinct from other insurers' market share in that RRGs are not bound by the same operating rules.

To measure concentration, we shall use the traditional Herfindahl index. This H-index is calculated for each year for each state as the sum each insurance company's squared market share so that $H_{j t}=\sum_{i}\left(w_{i j t}\right)^{2}$, where $w_{i j t}$ is the market share of company $\mathrm{i}$ in state $\mathrm{j}$ at time t. Suppose that a subset of the companies are risk retention groups (say companies 1 through $n$ ), our hypothesis is that $H_{j t}$ is negatively related to the market share of all risk retention groups measured as $M_{j t}^{R R G}=\sum_{i=1}^{n} w_{i j t}$ for year $\mathrm{t}$ and state $\mathrm{j}$.

In terms of our second main testable hypothesis, we want to examine the impact of risk retention groups on insurer profitability. Insurer profitability can come from three sources: underwriting performance, investment performance and operational performance. To do so, we shall use the most commonly profitability measure for insurers, namely the loss ratio. The loss ratio is calculated as incurred losses divided by earned premiums. Because of the presence of important outlier observations with respect to this variable (there are many firms that have almost no premiums, but very large losses, or the opposite) we opted to use the median loss ratio in the state as the appropriate insurer profitability measure. We expect the market share of risk retention groups to have a positive impact on the loss ratio so that the more important the presence of RRGs in a state in a year should drive insurer profitability down (an insurance affordability up, presumably).

Table 2 below highlights our regression results. It is important to note that although state and time fixed effect parameters were included in the regression, they are omitted from the table to make it more readable. It is clear in the table that the two main hypotheses 
of our paper are supported in that the presence of risk retention groups in the medical malpractice liability insurance market reduces insurer market concentration and profitability, although the impact on profitability (the inverse of the loss ratio) is not statistically significant. This means that the greater the market share of RRGs, the greater should be insurance availability and affordability in a state.

\begin{tabular}{|c|c|c|}
\hline \multicolumn{3}{|c|}{$\begin{array}{l}\text { Table 2. Ordinary Least Squares Regression Results: State- } \\
\text { level Medical Malpractice Liability Insurance industry } \\
\text { concentration and profitability as a function of the market } \\
\text { share importance of risk retention groups, } 1992-2006\end{array}$} \\
\hline & Herfindahl & Loss Ratio \\
\hline $\begin{array}{l}\text { RRG market } \\
\text { share }\end{array}$ & $\begin{array}{l}-0.111^{\star \star} \\
(0.056)\end{array}$ & $\begin{array}{c}0.224 \\
(0.205)\end{array}$ \\
\hline $\begin{array}{l}\text { Number of } \\
\text { insurers ('000) }\end{array}$ & $\begin{array}{l}-2.096^{\star * \star} \\
(0.206)\end{array}$ & $\begin{array}{l}2.863^{\star * *} \\
(0.680)\end{array}$ \\
\hline Lag loss ratio & $\begin{array}{l}-0.021 \\
(0.009)\end{array}$ & \\
\hline Unemployment & & $\begin{array}{c}0.017^{\star} \\
(0.010)\end{array}$ \\
\hline $\mathrm{R}^{2}$ & 0.177 & 0.28 \\
\hline \multicolumn{3}{|c|}{$\begin{array}{l}\text { Value of beta coefficient with standard error in parentheses. }{ }^{*},{ }^{* *} \text {, and } * * * \\
\text { denote significance at the } 90 \%, 95 \% \text { and } 99 \% \text { confidence level, } \\
\text { respectively. Both regressions include state and year fixed effects and } \\
\text { robust standard errors are reported. The number of observations in every } \\
\text { regression is } 700 \text { ( } 50 \text { states, } 14 \text { years). }\end{array}$} \\
\hline
\end{tabular}

The fact that the loss ratio does not seem to be significantly affected by the presence of risk retention groups in a state could appear to be problematic at first glance, but it is not disastrous. The state's loss ratio in the table is calculated as the incurred losses divided by earned premium. This is a measure of insurer profitability that is widely accepted, but that focuses exclusively on the underwriting side of the business without taking into account the overall operational efficiency. Missing from the loss ratio variable are the expenses that insurers incur to sell their policies as a proportion of total premium written. 


\subsubsection{Expenses}

Insurer operating efficiency is often assessed using the expense ratio, defined as the total of other underwriting expenses (expenses other than claims payments) divided by premiums written. This ratio can be added to the loss ratio to obtain the combined ratio, another commonly used measure for assessing performance. Unfortunately, the expense ratio is not available by state, but only company-wide. This prevents us from assessing efficiency across states, but we can use the firm-level expense ratios for comparisons. Because of the relatively small number of risk retention groups that were organized as mutuals or reciprocals in the earlier years of our study, we focus in Table 3 only comparing the expense ratios of traditional stock insurance companies with stock risk retention groups. Table 3 reports the median expense ratios for stock companies of each ownership type for our period of study.

\begin{tabular}{|c|c|c|c|c|}
\hline \multicolumn{5}{|c|}{$\begin{array}{l}\text { Table 3. Median Expense Ratios for Traditional Stock Insurance } \\
\text { Companies and Stock Risk Retention Groups, 1992-2006 }\end{array}$} \\
\hline \multirow{2}{*}{ Year } & \multicolumn{2}{|c|}{$\begin{array}{l}\text { Traditional Stock } \\
\text { Insurance Companies }\end{array}$} & \multicolumn{2}{|c|}{$\begin{array}{l}\text { Risk Retention Group } \\
\text { Stock Companies }\end{array}$} \\
\hline & $\begin{array}{l}\text { Expense } \\
\text { ratio }\end{array}$ & $\begin{array}{l}\text { Number of } \\
\text { insurers }\end{array}$ & $\begin{array}{l}\text { Expense } \\
\text { ratio }\end{array}$ & $\begin{array}{l}\text { Number of } \\
\text { insurers }\end{array}$ \\
\hline 1992 & 0.308 & 270 & 0.256 & 7 \\
\hline 1993 & 0.302 & 267 & 0.217 & 7 \\
\hline 1994 & 0.297 & 277 & 0.271 & 7 \\
\hline 1995 & 0.297 & 290 & 0.206 & 8 \\
\hline 1996 & 0.303 & 291 & 0.244 & 8 \\
\hline 1997 & 0.313 & 265 & 0.207 & 13 \\
\hline 1998 & 0.315 & 296 & 0.332 & 11 \\
\hline 1999 & 0.315 & 294 & 0.241 & 11 \\
\hline 2000 & 0.289 & 243 & 0.257 & 11 \\
\hline 2001 & 0.296 & 268 & 0.261 & 12 \\
\hline 2002 & 0.256 & 245 & 0.229 & 15 \\
\hline 2003 & 0.249 & 288 & 0.259 & 24 \\
\hline 2004 & 0.258 & 257 & 0.267 & 45 \\
\hline 2005 & 0.271 & 237 & 0.284 & 52 \\
\hline 2006 & 0.283 & 222 & 0.246 & 54 \\
\hline $\begin{array}{c}\text { Average } \\
1992-2006\end{array}$ & 0.290 & & 0.252 & \\
\hline $\begin{array}{c}\text { Average } \\
\text { 1999-2006 }\end{array}$ & 0.277 & & 0.256 & \\
\hline
\end{tabular}


The median expense ratio is, on average, greater for traditional stock insurance companies that for stock RRGs for the entire period 1992-2006. Stock RRGs appear to be more efficient than traditional stock insurers even in the latter period of 1999-2006. In fact, for the 15 years for which we have data, stock risk retention groups have a lower expense ratio than traditional stock insurers for 11 years. Of the four years where the median traditional stock insurer appears more efficient than the median stock RRG, three occurred in the last four year of the period under study (2003, 2004 and 2005). This could suggest that the pressure exercised by risk retention groups induced traditional medical malpractice insurance companies to increase their efficiency, at least in terms of their expense ratio.

\subsubsection{Reserving errors}

Bringing our attention now to the risk bearing ability of the different organizational forms, our hypothesis is that risk retention groups, because of their inability to access the capital market or to use state solvency funds, should put more effort in assessing their future losses. A way to measure this loss predictability power is to compare the variations in the different insurers' developed losses over their first five years of existence.

Our main hypothesis is that if risk retention groups have more to lose by not estimating correctly future losses than stock companies, then we should observe smaller reserving errors for RRGs than for stock companies (see also Lei and Schmidt, 2006). This hypothesis is related to the management's conscious decision to invest in proper loss assessment procedures. A related testable hypothesis we can also test is that incurred losses associated with OCC policies should be more difficult to predict than incurred losses for CMR policies because of the greater uncertainty regarding future losses that are not diversifiable.

To conduct this analysis, we need to construct a statistic that would be correlated with reserving errors. And because our focus is on reserving errors rather than the sign of these errors and because of the long tail nature of medical malpractice insurance, we need to construct a statistic that would take into account all the absolute size of the errors as well as their cumulated aspect over many years. This reserving error must also be scaled by the insurer's total book of business as the larger insurers' reserving error could be large in value, although it may be small relative to the total size of the book of 
able to sustain catastrophic events the least. At the other end of the spectrum, stock insurers have more leeway in establishing reserves because they are better able to access the capital market when they need.

The above results tell us that by giving physicians the right to structure their insurance company as a risk retention group, legislators may be able to reduce the volatility in the market. If one presumes that underwriting cycles are caused by capital shocks or the inability of insurers to predict correctly the losses, then it is quite possible that having more risk retention groups, which appear to better anticipate future losses, will reduce the negative impact of underwriting cycles.

\subsubsection{Entry in prior approval states}

Another aspect of the medical malpractice insurance market that needs to be studied so that we can get a better understanding of whether risk retention groups will increase insurance availability in the medical malpractice insurance market is where RRGs decide to enter the insurance market. Table 5 presents the number of new insurers by year as a function of the regulatory environment in the states (prior approval or not) and the ownership structure (risk retention group or not).

Table 5 shows that the medical malpractice industry entered a complete overhaul in the early years of the $21^{\text {st }}$ century with, on average, 118 new entrants per year from 2001 through 2006 in prior approval states and 112 entrants in states without prior approval compared to 25 and 24 respectively in the years 1992 through 2000, on average. And although risk retention groups represented a greater proportion of new entrants in prior approval states (37\% of new entrants since 2001 are RRGs in prior approval states compared to $35 \%$ in states without prior approval), the difference is not significant. The same conclusion can be reached for the years 1992 through 2000 (19\% in prior approval states versus $16 \%$ in states without prior approval). Based on these results, we can presume that a state's regulatory structure does not seem to play an important role in determining whether medical malpractice insurers choose to be incorporated as a risk retention group or as a traditional insurer.

It is also interesting to note that Pennsylvania appears to be the most popular state for RRG entry since 2001. In particular, one third of all RRGs in 2003 decided to enter Pennsylvania. This suggests that, perhaps, there are things other than prior approval 
that drives in what states risk retention groups decide to locate, such as a very peculiar medical malpractice insurance availability problem among particular groups of physicians. Nevertheless, the rate regulation regime does not seem to have an impact on an insurer's decision to be incorporated as an RRG.

\begin{tabular}{|l|c|c|c|c|}
\hline \multicolumn{6}{|c|}{ Table 5. Entry of risk retention groups in states with and without prior approval } \\
rate regulation, 1992-2006
\end{tabular}

The entry of RRGs into the medical malpractice insurance industry has not been as smooth as the figures above might suggest. As a group, the RRGs now capture a large share of the market, but many individual RRGs were not successful. Among the RRGs we were able to identify in the period we analyze, eleven RRGs were declared insolvent and/or voluntarily ceased operations, five merged with another RRG or a propertycasualty company, six dissolved without having ever becoming operational, and 15 converted from an RRG to another organizational form.

\subsubsection{Single vs. multiple state operations}

Another worry one may have in using risk retention groups as a natural experiment of the impact of an optional federal charter on the property and casualty insurance industry is that we are not comparing companies that have the same possible geographic presence. This argument is not entirely valid because the federal Liability Risk Retention 
Act of 1986 allows RRGs to underwrite risks in other states once licensed in at least one state. Interestingly, more than half of the RRGs providing coverage in 2005 were operating in 3 or more states, as we can see in Table 6.

\begin{tabular}{|c|c|}
\hline \multicolumn{2}{|c|}{$\begin{array}{l}\text { Table 6. Number of risk retention groups operating } \\
\text { in one or more states, by contract type, } 2005\end{array}$} \\
\hline & Total \\
\hline 1-2 states & 39 \\
\hline 3-10 states & 29 \\
\hline $11-25$ states & 7 \\
\hline $25-40$ states & 7 \\
\hline More than 40 states & 8 \\
\hline Total & 90 \\
\hline \multicolumn{2}{|c|}{$\begin{array}{l}\text { Source: NAIC State Page data. Counts include only firms with } \\
\text { positive premiums written in medical malpractice each year. } \\
\text { State counts include the District of Columbia, American } \\
\text { Samoa, Guam, Puerto Rico, and the American Virgin Islands. }\end{array}$} \\
\hline
\end{tabular}

With the advent of risk retention groups, insurers that were only selling occurrence policies were no longer able to compete in single states. As a result insurers interested in providing occurrence coverage to their policyholders had to diversify their risk geographically by selling policies in more states. As a result, whereas only $10 \%$ of insurers selling only OCC contracts were present in the 50 states in 1992 and 1998, $56 \%$ do so in 2005 . The same geographic diversification trend is also observable for insurers selling CMR contracts only and for insurers selling both contract types. The scale efficiency hypothesis implies that firms operating at an optimal scale achieve lower costs and higher profits. We can therefore see that the geographical distribution of risk retention group operations is similar to what we should expect from property and casualty insurers that opt for a federal charter.

\subsection{Risk retention groups versus optional federal charter insurer}

Our entire argument in this research paper rests on the fact that we are using the presence of risk retention groups in the medical malpractice insurance industry as an approximation of what would happen to the property and casualty insurance industry if insurers could opt for an optional federal charter instead of state incorporation. For such an argument to be valid, we need to show that the leap from a risk retention group to a federal charter insurance company is not very big. To do so, we show in the remainder 
of this section that risk retention groups have some flexibility in the type of product they sell and in the number of states they operate in, just as federally chartered insurers would. Table 7 presents the market share of insurers as a function of their ownership structure (stock company, mutual, reciprocal, risk retention group, or other types of ownership) as well as a function of the type of contract they sell (occurrence only, claims-made only, or both) for three specific years: 1992, 1998 and 2005.

\begin{tabular}{|c|c|c|c|}
\hline \multicolumn{4}{|c|}{$\begin{array}{l}\text { Table } 7 \text {. Market Shares by Ownership Structure, Contract } \\
\text { Type and Selected years (1992, } 1998 \text { and 2005); all insurers }\end{array}$} \\
\hline & 1992 & 1998 & 2005 \\
\hline \multicolumn{4}{|c|}{ Panel A: Insurers selling only occurrence policies } \\
\hline Stock & $79.20 \%$ & $98.90 \%$ & $78.87 \%$ \\
\hline Mutual & $19.46 \%$ & $0.88 \%$ & $7.62 \%$ \\
\hline Reciprocal & $0.64 \%$ & $0.09 \%$ & $0.00 \%$ \\
\hline Risk retention groups & $0.50 \%$ & $0.08 \%$ & $13.52 \%$ \\
\hline Others & $0.20 \%$ & $0.04 \%$ & $0.00 \%$ \\
\hline \multicolumn{4}{|c|}{ Panel B: Insurers selling only claims-made policies } \\
\hline Stock & $43.33 \%$ & $66.48 \%$ & $55.01 \%$ \\
\hline Mutual & $9.88 \%$ & $15.46 \%$ & $7.96 \%$ \\
\hline Reciprocal & $39.26 \%$ & $5.68 \%$ & $6.33 \%$ \\
\hline Risk retention groups & $7.53 \%$ & $11.86 \%$ & $30.63 \%$ \\
\hline Others & $0.00 \%$ & $0.52 \%$ & $0.07 \%$ \\
\hline \multicolumn{4}{|c|}{ Panel C: Insurers selling both types of policies } \\
\hline Stock & $59.49 \%$ & $56.77 \%$ & $49.14 \%$ \\
\hline Mutual & $25.93 \%$ & $25.79 \%$ & $32.27 \%$ \\
\hline Reciprocal & $13.58 \%$ & $15.48 \%$ & $14.74 \%$ \\
\hline Risk retention groups & $0.93 \%$ & $0.85 \%$ & $3.36 \%$ \\
\hline Others & $0.07 \%$ & $1.11 \%$ & $0.40 \%$ \\
\hline \multicolumn{4}{|c|}{$\begin{array}{l}\text { Source: NAIC State Page data. Counts include only firms with positive } \\
\text { premiums written in medical malpractice each year. * State counts } \\
\text { include the District of Columbia, American Samoa, Guam, Puerto } \\
\text { Rico, and the American Virgin Islands. }\end{array}$} \\
\hline
\end{tabular}

Looking at Panels A and B of Table 7 (occurrence only and claims-made only), we see that the market share of stock companies varied very differently depending on the type of contract that was sold. Indeed, whereas the market share of stock companies did not 
vary much in the case of insurers selling only CMR insurance contracts between 1992 and 1998, the market share of stock companies increased by almost ten percentage points in the case of insurers selling only occurrence policies. In the case of insurers selling both types of contract (Panel C), stock companies increased their market share between 1992 and 1998, but only marginally so.

From 1998 until 2005, the market share of stock insurance companies dropped by ten percentage points or more in all three panels. This drop in market share coincides with a rapid emergence of risk retention groups as a popular ownership structure, especially when the insurance contract is claims-made. This suggests that the insurance product sold by risk retention groups caters more directly to the need of policyholders. Moreover, insurers could have incorporated themselves as reciprocal or mutual insurance companies to achieve some of the most important advantages of risk retention groups, but reciprocal insurers do not seem to enjoy the same popularity are risk retention groups.

As we show in a companion paper, ${ }^{20}$ firm concentration decreased for claims-made contracts over the past decade, but it increased for occurrence contracts. As a result, the current market for claims-made policies is a lot less concentrated than the market for occurrence policies. A possible interpretation of why the claims-made market is less concentrated is that it is primarily this type of contract that risk retention groups decided to offer when they came to the medical malpractice insurance market. Put differently, entry by new insurance companies was more prevalent in the claims-made insurance line than in the occurrence line

\section{Conclusion}

The goal of our research was to use the increasingly important presence of risk retention groups in the medical malpractice liability insurance market as a test of the impact of optional federal charters on insurance availability and insurer profitability in other property and liability line of business. This test is, of course, dependent on whether risk

${ }^{20}$ Patricia Born and Martin Boyer (2008). Claims-Made and Reported Policies and Insurer Profitability in Medical Malpractice, CIRANO working paper 2008s-15. 
retention groups could be construed as a reasonable proxy for insurers that would operate under a federal charter. Our argument revolved around the fact that the only advantage of being a risk retention group over a state-incorporated stock company must come from the regulatory side rather than the financial and/or economic side of the business.

Risk retention groups, by having the right to be incorporated in one state and allowed to write business in many, are the closest thing to be federally chartered insurance companies. In that sense, our use of risk retention groups to assess the impact of optional federal chartered insurers on product availability is valid. This is more so given one alternative to a federal charter exposed by Prof. Scott Harrington: ${ }^{21}$

"The alternative (to an OFC is) to designate a primary state and to operate nationwide subject primarily to the regulations of that state might have the potential to improve significantly the performance of insurance regulation with relative simplicity, less risk, and without creating a federal regulator."

The main point of our research was to show that the presence of risk retention groups decreases the concentration of the insurance industry, as measured by the Herfindahl index, and as such increases insurance availability. Risk retention groups are also associated with a lower reserving error volatility, which suggests, perhaps, that they are less prone to manipulate aggressively their reserves than insurers regulated at the state level.

It is true that risk retention groups differ from federally chartered insurers in the sense that federally chartered insurers would not need to obtain "prior approval of policy form and rate regulation for nationally licensed lines" ${ }^{22}$ whereas risk retention groups still do. According to Prof. Sharon Tennyson, ${ }^{23}$ the optional federal chartering of insurance

${ }^{21}$ Scott Harrington (2006), Federal Chartering of Insurance Companies: Options and Alternatives for Transforming Insurance Regulation, Networks Financial Institute policy brief 2006-PB-02;

${ }^{22}$ Hal S. Scott (2007), Optional Federal Chartering of Insurance: Design of a Regulatory Structure, Harvard University Law School Public Law research paper 07-05.

${ }^{23}$ Sharon Tennyson (2006), Efficiency Consequences of Rate Regulation in Insurance Markets, Networks Financial Institute policy brief 2007-PB-03. 
companies would eliminate insurance rate regulation and risk classification. Our results show that risk retention groups are not no more likely to enter in tightly regulated states (i.e., prior approval states) than traditional insurers. This is perhaps an indication that Tennyson's hypothesis is correct since the regulatory environment has no impact on the propensity of risk retention groups to enter any given state.

One last question we did not address in this paper is whether the presence of risk retention groups increased (or decreased) the propensity of insurers to become insolvent. This question would be of prime importance especially if one holds the opinion $^{24}$ that multi-state jurisdiction reduces the regulator's ability to oversee the market because of regulatory free-riding problems and income shifting across states. Given, however, that risk retention groups are less prone to reserving errors, we may anticipate that solvency problem would be less prevalent. On the other hand, we showed that the increase in the number of risk retention groups coincided with a decrease in the number of other organizational forms of medical malpractice insurance companies, especially stock insurance companies. If the reduction in the number of traditional insurers is the result of a plethora of insolvencies rather than of a wave of mergers and acquisitions, then it is possible that the presence of risk retention groups increases the propensity of insurers to become insolvent. But these insolvencies would be the result of risk retention groups being a better mouse trap than traditional organizational forms.

The question that we must ask ourselves at this point is to what extent the results we found for the medical malpractice liability insurance line would be the same or different than across other lines in which an optional federal charter would be obtained. This question raises much speculation so that the best one can offer is a guess as to the impact on other lines of business of optional federal chartering. The empirical results we present in this paper are to the flavor that optional federal charters would increase insurance product availability to policyholders in the United States.

${ }^{24}$ See Martin F. Grace and Richard D. Phillips (1999), The Allocation of Governmental Regulatory Authority: Federalism and the Case of Insurance Regulation, Georgia State University Center for Risk Management and Insurance Research working paper 96-26; and Hal S. Scott (2007), Optional Federal Chartering of Insurance: Design of a Regulatory Structure, Harvard University Law School Public Law research paper 07-05. 